\title{
A KANTIAN APPROACH TO HENRI BERGSON'S CONCEPT OF OBLIGATORY MORALITY
}

John Igbogo Ebeh ${ }^{1}$

\begin{abstract}
The paper uses Immanuel Kant's moral principles to examine the concept of obligatory morality by Henri Bergson. Henri Bergson holds that the society is the cause and source of obligation which obviously implies that the sense of obligation is a sense of social pressure. Accordingly, the voice of duty is not something mysterious coming from an unimaginable world but rather, the voice of the society. Accordingly, if one conforms to the directives of these rules it would mean resistance to self. Hence, when one is morally obliged to act in a specific way, he refers to a belief that the act is one prescribed by a set of values. Kant's categorical imperative holds that if an act is cleared to be performed it should be universalized for any other person in similar situation to perform such action. The question therefore is: how do we reconcile the dictates of the society with the categorical imperative of Kant? The paper is expository in nature, critical in outlook and analytical in method. It uses Kant's ethical standard as its modus operandi in the discourse of Henri Bergson's obligatory morality.
\end{abstract}

Keywords: Obligatory Morality, Open Morality, Closed Morality, Societies in the Individuals.

\section{INTRODUCTION}

Morality is a fact in every society; its importance in every society cannot be over emphasized. This is because no society can exist without morality. The premise of this essay is that although there can be obligation to a certain degree in the society, the idea remains valid that the morality of aspiration and overwhelming personal conviction persist as the most future and progressive moral subscription.

Moral obligation in brief, is an obligation arising out of a consideration of right and wrong. This consideration of rightness and wrongness depends solely on the dictates of the society. Bergson puts this better when he says "the society is the cause and source of obligation (Bergson 95)". The outright implication of this submission is that, the sense of obligation is a sense of social pressure. The voice of duty is not something mysterious, coming from an unimaginable world, rather, the voice of the society. Conforming to the directives of these rules would therefore mean resistance to self. Hence, when one is morally obliged to act in a specific way, He

\footnotetext{
${ }^{1}$ Senior Lecturer, Dept. of Philosophy and Religion, Kogi State University. Ph.D, African Philosophy (KSU Anyigba). M.A., Ethics and Philosophy (UniJos).E-mail: ebeh4u@gmail.com
} 
refers to a belief that the act is one prescribed by a set of values. It is a morality of the ordinary man whose horizon does not go beyond the society in which He lives. More so, it impedes the creative potential of man: hence, the only obvious product of obligation is evolutionary retardation.

The open morality of Bergson is headed in contrary direction with obligation as understood in a closed society. This morality transcends the confines of obligation and imposition. It is also a dynamic society which extends its tentacles far beyond family, tribal and national interests and opens itself to the interest of mankind at large. The least point that could be made about the Bergsonian initiative is that, it engenders freedom of moral expression, though not arbitrary expression, but one that springs convincingly from emotion and aspiration.

Obligation has been inherited as a take away from the acrimonious, anarchic and brutish community of human beings. Obligation was expected to soft-pedal the inhumanity of man to man as experienced in the state of nature. With the sole intention of solving the so many problems arising from the state of nature, it has also caused a lot of problems. Every facet of the society has been adversely affected by this deleterious virus of absolute obligation. In the religious sector, there is spiritual set back as a direct resultant effect of a myriad of inconsequential rules: in the educational sector geniuses and intellectual wizards cannot make any meaningful contribution to the society. This of course is a fall out from the so many hurdles that have to be crossed in terms of rules. Our political system is gradually dwindling because people do not have the right attitude toward public service.

In all these, one of the things that cannot in anyway be relegated to the background is the statement of reality that is, one only thinks about the obligation in a society that is laden with laws. The interest and progress of others mean nothing. Satisfying the law becomes the utmost goal. Though these laws sometimes might mean a privation of another's freedom, less attention is paid to it. Hence, we might only be stating the obvious saying that is obligatory morality is still inhumanly of man to man. If we must have a full grasp of this issue of societal preservation and the palatable shortfall of adherence of laws without proper understanding, then we must make a hurried mention of the assertion of Hegel (1967:32) when he say that:

Civilization is falling apart: society is on the Brink of collapse. The media is rife with news of war and rumors of war. Suicide bombers daily blow up lanes, cars and buildings, killing in violent people: there is a mad rush for nuclear weapon and an amazing desire for nations to build formidable arsenals.

All these weird contemporary engagement of man show cases the ignorance of his duty towards his neighbours. These anomalies are good signs that even in the midst of obligation and pressure from the society: people lack the basic understating of the reasons for obligation. In a simpler term, compliance with societal law is chiefly by the instrumentality of force.In a frantic search for a profitable and enviable morality, comes the dynamic and open morality of Bergson. It is headed in a contrary direction to obligation. It addresses and suggests a kind of morality which is born out of emotion, aspiration and desire. The emphasis lies more on the 
duty of man to man and the entire humanity for the sake of love.

In order to make an accelerated rescue of the society from the grip of an in-depth loyalty to obligation, Bergson's open and dynamic morality serves as a superlative tool to challenge the problem of obligatory morality. Every act of man is better done in an unrestricted and free atmosphere. This paper attempts a presentation of a kind of morality that emanates from emotion and aspiration. It is examined against the backdrop of Kant's categorical imperative which holds that any act that is deemed right should be universalized.

This paper is burdened with the challenge of creating the Bergsonian open morality in contradistinction with morality of obligation. Bergson's notion of emotion as the premier source of creativity shall be properly show cased. Over and above all, the work presents a society that embodies the universe at large and not just one concerned with self-presentation. For the individual to be less aware of resistance to pressure from the society and for a universal peaceful co-existence, the society must encourage a sense of morality that is not just aimed at societal preservation and defense but that which is committed to all humanity.

\section{HENRI BERGSON'S CONCEPT OF MORALITY}

Bergson is sometimes depreciated as a philosopher due to his high-flown to rhapsodic style and a certain lack of precision in his thought. This relegating exercise of course is an activity of those who equate philosophy with logical or conceptual analysis and who attach great value to precision of thought and languages. Thus, Bergson placed due consideration on morality-the greatly preferred are the open and closed morality.

\section{Closed Morality}

Bergson (1935:9) begins his treatment on morals with reflection on man's sense of obligations. He commences his theorizing with an apt assessment of our childhood. In his words what a childhood we should have had if only we had been left to do as we are pleased! We should have flitted from pleasure to pleasure, but all of a sudden an obstacle arose, neither visible nor tangible: a prohibition.

Why did we obey? The question hardly occurred to us. We have formed the habit of deferring to our parents and teachers. All the same, we knew very well that it was because they were our parents, because they were our teachers. Therefore in our eyes, their authority came less from themselves than from their status in relation to us. They occupied a certain station; that was the source of the command which had it issued from some other quarters, would not have possessed the same weight. In other words parent and teacher seem to act by proxy.

In an attempt to clarify this all important reflection on the parents and teacher and the child, Bergson states how it works and its relationship with the society. Hence he says we did not fully realize that but behind our parents and teachers we have an enormous, or rather some shadowing things that exert pressure on us through 
them. Later we would say it was society (Bergson 1935:9).

The above brainchild of Bergson could validly be compared with the existence and activities of an organism. He says:

... an organism whose cells, united by imperceptible links, fall into their respective places in a
highly developed hierarchy, and for the greatest good of nature submit to a discipline that
may demand the sacrifice of the part. Thus, however, can only be a compassion, for one
thing, and a society composed of free will. But once these wills are organized, they assume the
sense of an organism; and in this more or less artificial organization, habit plays the same role
as necessity in the work of nature (Bergson 1935:10).

Social life perceived in this direction is a system of more or less deeply rooted habits, corresponding to the need of the community. Some of them are habits of command, most of the habits of obedience. Whether we obey a person commanding by virtue of a mandate from society or from the society vaguely perceived or felt, there emanate an impersonal imperative, which pressurizes our will. We can evade it, but then we are attracted towards it, drawn back to it like a pendulum which has swung away from the vertical. A certain order of things has been upset, it must be restored. In a word, as with all habits, we feel a sense of obligation in closed morality.

\section{Societies in the Individual}

Each of us belong as much to the society as to himself. While the consciousness of delving downwards reveals to us the deepness of an ever more original personality, incommensurable with the others and indeed indefinable in words. On the surface of life, we are in continuous contact with other men and women that we resemble and unite with by relation of interdependence (Bergson 1935:14).

By this, we can easily infer that humans are unconsciously attached to the society through an inner interaction with the society that resides therein. Humans are in one way or another entrenched in the society and we scarcely need to seek out. Although it has been confirmed that no one can completely cut himself off from the society and no one would wish to do so, for the fact of perfect awareness that a greater part of his strength comes from thus sources, and that we owe to the ever-recurring demand of social life that unbroken tension of energy that steadiness of an effort which ensures the greatest return for our activities. Whatever human do, is done under the supervision of the society because his memory and his imagination live on what society has implanted in him.

As a direct correlation of the above, it should be noted that the language spoken by man has an element of the society inherent in it and because even if there is no one present, even if he is merely thinking, he is still talking to himself. Vainly therefore, do we try to imagine an individual cut off from social life.

The situation of Robinson Crusoe on his Island tends to be a perfect example of this tale we seem to be telling. In his case, Robinson Crusoe on his Island remained in contact with other men, for the manufactured object he saved from the week, and without which he cannot get along, keep him within the bonds of those of the 
society he draws energy from the society to which he remains attached in spirit, he may not perceive it, still it is there watching him. Strengthening this point, Henri Bergson (1935:16) states:

Those which circumstances condemns for a time to solitude, and who cannot find within themselves the resources of a deep inner life, know the penalty if given away; that is to say of not stabilizing the individual ego at the level prescribed by the societal ego.

Hence, practically detached from the society there is still socialization which of course calls more strongly via the consciousness of social ego. The case of Kipling's forest officer would serve a perfect example. For even alone in his bungalow in the heart of Indian Vulch, he dresses every evening for dinner so as to pressure his selfrespect in isolation.

Considering the case of hardened and desperate criminal, you might at first mistake his remorse for dread of punishment, but a more cursory look at it will make us understand that since the criminal has never been caught, he has no cause whatsoever to dread punishment. "But the society that constantly resides in him makes him necessarily guilty which is a clear relationship between the social and individual self (Bergson 1935:17).”

\section{Obligation, Obedience and Life}

According to Bergson (1935:18), "it takes a violent break to reveal clearly the task of the individual to the society." In the ordinary way, we conform to our obligations rather than think of them. In this sense, we talk of spontaneous obedience in the words of Bergson. This is a kind of obedience that comes impromptu as a result of mastery of the task and the duty at stake. If we have all the time to evoke the idea, enunciate the formula, it would be much more timing to do our duty. But habit is enough and in most cases we have only to leave well alone in other to accord the society what is expected from us. Against this backdrop, it could be quickly and even so correctly be stated that society occupies the circumference: the individual is at the Centre: from the Centre to the circumference are arranged like so many even widening concentric circles, the various groups to which the individual belongs. To this end Bergson (1935:18) states:

... society has made matters very much easier for us by interpolating intermediaries between itself and us; we have a family, we follow a trade or profession, we belong to our Parish, to our district, to our country and in cases where the insertion of the group into the society is complete, we may content ourselves, if need be with fulfilling our obligations towards the group and so paying our debts to society.

The above statement implies that the society draws up for the individual the programme of his daily routine. It seems impossible therefore to embark on our quotidian activities without obeying rules and submitting to obligations. This obligation and obedience sometimes appears strenuous, harsh and unbending, obviously because there occur cases where obedience implies an overcoming of self. For however, naturally we do our daily duty we may meet with resistance within ourselves; it is wise to expect it and not take for granted that it is easy to remain an honest fellow. It is dangerous to say duty can be done automatically; hence we can set up as a practical 
maxim that obedience to duty is resistance to self.

\section{BERGSONIAN CONCEPTIONS OF SOCIETY AND OBLIGATION}

The complexity of Bergsonian analytical pattern makes it fatally important that we should assess the foregoing ideas of Bergson before considering his concept of society and then obligation properly. The first task here becomes, what is Bergson's conception of 'society'. By society Bergson seems to means the context of closed society, as he expresses it. This may be a particular society which is conscious of itself as this society distinct itself from other closed societies. It is from society in this sense that obligation emanates and the function of the social pressure which gives rise to this sense of obligation in individual members of the society is to maintain the society's cohesion and life.

The second question which is the meaning of obligation as continued by Bergson, seems to be a more tasking question to attempt. Obligation seems to mean a feeling or sense of duty. Bergson sometimes speaks of the awareness of obligation as the awareness of social pressure. Frederick Copleston (1975:205), also helps us to understand the meaning of obligation in Bergson when he write that:

Bergson uses the word obligation in several sense that is to say, it is at any rate clear that for him the efficient cause of obligation is the pressure exercised on its members by closed society, and that its final cause is the maintenance of the society's cohesion and life.

Obligation is thus, without reflection, relative to the closed society and has a social function. The origin of obligation is intra-intellectual. In a society such as those of bees and ants instinct takes care of social cohesion and services to the community. If however we imagine a bee becoming self-conscious and capable of intellectual reflection, we can picture it asking why it should continue to act as it has been hitherto acting by instinct. At this point, we can see social self, the awareness of this pressure being a sense of obligation. Social pressure and obligation are the means used by nature to secure society's cohesion and preservation. Hence, the morality of obligation is of infra-intellectual origin.

As a concluding remark on this point it will be helpful to acknowledge the statement of Copleston in this regard, he states:

Preservation of a society's cohesion is obviously not secured simply by pressure of observe rules which would be classified as moral rules by members of an advanced society's accustomed to differentiate between social conventions and ethical norms (1975: 206).

A primitive society, when looked at from one point of view, extends the coverage of moral obligations to rules of conduct which would be unlikely to classify as civilization in progress, the human reason starts to discriminate between rules of conduct which are genuinely necessary and those useful. When a rule has been subjected to radical questioning by human intelligence, the mind will look for reason to support the code. 


\section{OPEN AND DYNAMIC MORALITY}

At last come very close to the morality that is creative, and the morality of freedom. This morality is open in the sense that it strives to change society not simply to pressurize it as it is.

The morality of obligation, relative to the closed morality is not regarded by Bergson as contaminants with the whole field of morality. He is well aware that the moral idealism of those individuals who embodied in their own lives values and standard higher and more universal in their effect that the current ethical codes of the societies in which they belonged cannot be easily explained in terms of the social pressure of a close group. Bergson therefore asserts that the existence of a second type of morality which is different in kind from the morality of obligation.This kind of morality of course is characterized by appeal and aspiration, and it relates to man as man or to the ideal society inhabited by human beings rather than to the closed society in any of its forms. Consider for example a historical figure who not only embodied it in his own universal love but the ideal, so embodies acts by way of attraction and appeal rather than by way of social pressure, and those who respond to the ideal are drawn by example than impelled by the sense of obligation which expresses the pressure of a closed group.

\section{THE ATTRACTIVE POWER OF OPEN MORALITY}

In all times there have arisen exceptional men, incarnating this morality, before the Saints in Christianity; mankind have known the stages of Greece, the prophets of Israel, the Adherents of Buddhism and others. It is to them that men have always turned to for that complete morality which we have best called absolute morality. And this very fact is at once characteristic and instructive. This very fact suggests to us the existence of a difference of kind and not merely the degree between obligation and dynamic morality. Now it should be noted that the call of the Hero as used by Bergson means that a privileged person becomes an example for others to emulate. The generality of the former morality consist in universal acceptance of a land, perhaps that of all other in a common imitation of a model. This kind of morality which undoubtedly, has a face of appeal is what Bergson contrasted with the former via this question:

Why is it, then, that Saints have their imitators and why do the great moral leaders draw the masses after them? They have no need to exhort; their mere existence suffices. For such is the nature of this other morality. Whereas natural obligation is a pressure or a propulsive force, complete and perfect morality has the effect of an appeal (Bergson 1935: 34).

The attraction does not necessary require a personal experience of the Hero in question, it might be one whose life story has just been told or we have read about the person. And in whatever case, we in our imagination and judgment submitted our will to place of action which has taken the place of natural obligation or rather which ends by absorbing it duties are in respect of humanity. These duties are clearly distinguished by Bergson as it is 
obvious in his statement:

The duties dealt with in the closed society are those imposed on us by social life; they are binding in respect of the city more than in respect of humanity. You might say that the second morality if we do distinguish the two differs from the first in that it is human instead of being merely social (Bergson 1935: 35).

Superimposed upon the human morality are the commitments of loyalty, sacrifice of self, the spirit of renunciation, charity such are the words we use when we think of these things. It suffices for us to know the moral attitude of the Hero or the person in question here. Just a very short retrospection and we would not have any problem recalling that the moral attitude of the individual in the close morality is that of the individuals and social soul moves round in a circle. In this case whatever the individual pauses in a little reflection on its activities, he will feel a pressure and this invariably invite resistance even if it is not an obvious or practical resistance.

The consideration above fall short of the standard of the moral attitude that the following words of Bergson described as the moral attitude of the open morality:

Suppose we say that it embraces all humanity; we should not be going too far, we should hardly be going far enough, since its love may extend to animals, and to plants of all nature. And yet, no one of all these which would in turn feel it would suffice to define the attitude taken by the soul for it could strictly speaking, do with one all of them (Bergson 1935: 38).

\section{PROPULSIVE FORCE OF EMOTION}

Emotion seems to be the driving force of imbibing values. The force that engenders this kind of submission and appropriation may be crucial at this point. Given this situation, we would have no choice than acknowledge the role of feeling in this kind of morality. The all-inclusive and overwhelming command of this feeling introduces a kind of commitment and submission that do not have any space for inordinate reflection and as a consequence, the feeling of resistance occupies no position other than that of a redundant spectator.

Fredrick Copleston in his simplification of the Bergsonian conviction of feeling comments that:

Though the open morality does in fact involve the ideal of the universal it is essentially characterized not so much by its content as by a vital impetus in the will which is quite different from social obligation or pressure. This vital impetus also described by Bergson as "emotion", is of suprarational origin (1975: 207).

When we assess love in its nascent taste, we discover that to a considerable length, the impulse given by feeling can indeed closely resemble obligation. We may therefore ask, is pressure the aim of love, could we not as well say it is pain?

\section{EMOTION AND CREATIVITY}

Emotion as it were begets thought; and invention, though it belongs to the category of the intellect, may vol.10, nº. 03, Rio de Janeiro, 2017.pp. 1775-1792 
partake of sensibility in the substance; for we must agree upon the meaning of the words "emotion", "feeling" and "sensibility". Bergson (1946: 43) defines emotion thus: "Emotion is an effective striving of the soul, but a surface agitation is one thing, an upheaval of the dept of another." The effect is in the first case diffused, in the second it remains undivided. We must distinguish between two kinds of emotion, two varieties of feeling, two manifestation of sensibility which have this one feature in common, that this emotional state is distinct from sensation and cannot be reduced, like the latter, to the physical transposition of physical stimulus. In the first place, the emotion is the consequence of an idea; the feeling is indeed the result of intellect that state which owns to it, which is selfsufficient and which if it does experience a certain reaction from the feeling, loses more than it gains. It is the striving of sensibility by a representation, as if it were dropped into it.

But the other kind of emotion is not produced by a representation, which it follows and from which it remains distinct. Rather is it in relation to the intellectual state which are supervened, a cause and not an effect. The second kind of emotion can alone be productive of ideas. Creation signifies, above all, emotion and that not in literature or art, alone. Emotion precipitates curiosity and desire and the anticipated joy of solving a stated problem. It is emotion which drives intelligence forward in spite of obstacles. According to Bergson (1946: 46):

It is thus same emotion which vivifies or rather vitalizes the intellectual element with which it is defined to unite, constantly encoding everything that can be worked in with them and finally compelling the enunciation of the problem to expand into its solution. A work of genius is in most cases the outcome of an emotion, unique of its kind which seemed to baffle expression and yet which had to express itself.

From the above, it becomes indubitable that it's so of all work, however imperfect into which there enters some degree of creativeness. Any one engaged in writing has been in position to feel the difference between an intelligence left itself and that which turns the fire of an original and unique emotion, born of the identification of the author with his subject, that is to say of intuition.

It became too vital and indeed acutely relevant to acknowledge the calibration of emotion into two disparate levels: The first is the original emotion which springs from the well of intuition; hence it needs no object or representation to excite it. On the other hand, the second level and of emotion is as a result of representation. This emotion does not precede the image which virtually contains it and to certain extent its cause. This emotion is excited within us by a great dramatic work. Emotion of this kind is still a resemblance of burning flame in the author; hence it was no more than creative eagerness which can only be satisfied once the work is finished.

By a way of conclusion, duties whose obligatory character is to be explained fundamentally by the pressure on the society on the individual and be readily granted because these duties are a matter of current practice, because they have a clear formula, and it is therefore easy for us by grasping them where they are entirely visible and then going down to the root, to discover the social requirements from which they spring. But that the rest of morality expresses a certain emotional state, that actually will yielded not a pressure by to an attraction, 
many people will hurriedly acknowledge. Thus, without any doubt, emanates from the fact that there is no standard outline or guide which should of course promise the society. It is against this development that Bergson eventually subscribed to the open morality which invariably is a kind of morality that is precipitated by emotion. The emotion which we speak about here is the enthusiasm of a forward movement; progress and advance more ever are in this case indistinguishable from the enthusiasm itself. Hence in the words of Bergson:

Between the first morality and the second lies the whole distance between reposed to be immutable if changes it immediately forgets that it has charged or it acknowledge no change. The shape it assumes at any given time claims to be the final shape. But the second is a forward thrust, a demand for movement: It is the very essence of mobility (1935: 58).

However, irresistible the obligatory morality is the validity of the Bergsonian assertion that obligatory morality is a sleeping and doubting one cannot be leisurely discarded. This cascades form the fact that it does not make any effort at evolving and or developing whereas the open morality can only be contented with its persistent evolution. We are therefore forced to believe in the continuous evolution of Bergsonism.

\section{AN APPRAISAL OF BERGSON'S OPEN MORALITY}

The promise of our argument here is that although there can be a certain degree of holistic openness in a political society; the idea still remains valid that all political society without exception in this generation are fundamentally closed with obligation. Thus means that no matter how progressive a particular society tends to be, it exists ultimately for the protection and advancement of the values and interest of a particular exclusive group and not for the defense or advancement of the values of humanity as a whole. Omoregbe puts this rightly when he says "the basic instinct in man is that of self-preservation" (2012:36).

If this assertion is of any relevance, then the society being a conglomeration of beings that have selfpreservation as then strongest instinct should expand a larger portion of its energy in the preservation of social interest. It is the selfish tendency that leads to strife and other inordinate delinquencies in the human community.

According to G.E Moore ethics is concerned only with free actions, that is, voluntary actions for which man is held responsible. A free action is an action which a man chooses to perform and while he could also choose not to perform. If a man decides to perform an action when he could also alternatively decided not to perform it his action is a free action (Omoregbe 2012: 40). This means that he was under no compulsion to perform that action since he could have done otherwise if he has chosen to do so; he is therefore responsible for the action whether it was good or bad one. People often indulge in a certain course of action because they are forced to.

The issue is that whenever we talk of force or compulsion, we do not talk of morality. Thence, if one is met by a thief, he or she will be forced to turn his or her money over to him if at all he has any, but if he or she refuses, he or she may be forced to suffer the consequences. In such a case, we will not ordinarily describe his or her actions as being voluntary actions or action done because he or she wanted to. In this instance, he or she is vol.10, n. 03, Rio de Janeiro, 2017. pp. 1775-1792 
not a free agent. He is properly described as not acting from inclination from duty but rather as being compelled to do so. It would be concluded that this action in which compulsion is used is not even a moral action; hence absolute obligation could not be any different from this situation. It is therefore a requisite of any act being done from inclination or duty that it be that act of a free agent. It is in freedom only that we can make a valid assertion about responsibility and in extension a claim of the knowledge of right and wrong. Joseph Omeregbe (2012:36) appears to capture the issue when he made a statement concerning the relationship between freedom and responsibility. He says for one to be free is Ipso facto to the responsible, there can be no freedom without responsibility. Freedom is not a heavy burden laid on him, for he is held responsible for the way he uses his freedom.

One must be free if he or she must be responsible for his or her actions or inaction. Hence, right and wrong could only be considered in relation to freedom. Absolute obligation should not have even been considered as a moral principle since it compels absolutely and the consequences of noncompliance are clearly mapped out. It is also of utmost importance not to misconstrue the terms of the freedom. Freedom as it were is not synonymous to success or ability to achieve one's aim. It is necessary to point out to common sense, says Jean-Paul Sartre: "that the formula to be free does not mean to obtain from what one has wished, but rather to determine oneself by oneself to which is the sense of choosing (Stumpf 1983: 481)." Freedom is concretely realized and exercised in choice or decision. Each time we make a choice, or a decision, we exercise our freedom. Sartre tells us that it is not possible for a free being to avoid making a choice thus:

Man is free to choose not to choose what he wants, but he is not free not to choose since a refusal to choose is already a choice made. To refuse to choose is in fact one way of choosing; to refuse to take a decision is already a decision taken ... freedom is the freedom is choosing. Not to choose is in fact to choose not to be free (Stumpf 1983: 483).

It has been established that man is not free not to be free. He cannot avoid being free for he is condemned to be free and whatever he decides to do so is an exercise of this freedom. However, man's exercise of his freedom is often observed by various factors of physical, psychological, social and environmental forces or violence.

One of the points that should be given adequate attention here is the fact that physical force or violence can render the exercise of freedom completely impossible, and consequently also remove moral responsibility. A man is completely removed from moral responsibility for an action performed in the state of insanity and under such a situation he or she could not have done otherwise.

Obviously, we can say that ethics is concerned only with free actions and this means that human freedom is a presupposition of ethics. Indeed it seems an obvious fact that man should be free if he must be responsible for his action. Walter T. Stace argues forcefully in favour of human freedom if there should be anything like morality. He says "it is certain that if there is no free will, there can be no morality (Oyeshile 1998: 
74)."

If we base our argument for foisting a particular kind of moral values on human beings on the delinquencies of the state of nature, then Bergson would revolt very quickly against that. Bergson attempted a classification of the developmental attitude of the vital impulse which is responsible for evolution. The vital impulse says Bergson, moves in three desirable directions, producing vegetation's, arthropods and vertebrate (including humanity). With these levels of evolution, we need not waste so much time in convincing anyone that evolution should have worked. Those self-seeking attitude and the inhumanity of man to man should have been drastically improved upon.

It is this same morality and concern for obligation that led to the development of the sophist that was tied around the government's order. Now, let us pay attention to this statement of Plato published in the first volume of Popper's book, "The spell of Plato" it reads:

The greatest principle of all is that nobody, whether male or female should be without a leader. Nor should the mind of anybody be habituated to letting him do anything at all on his own initiative, neither out of zeal or playfully, but in war and in the midst of peace to his leader he shall direct his eyes and follow him faithfully. And even in the smallest matter, he should stand under leadership. For example, he should set up, or move, or wash, or take his meals only if he has been told to do so in a word never to dream of acting independently and to become latterly incapable of it (Popper 1962: 7).

A cursory look at this citation would not limit anybody the access to the inhumanity of man to man's interest in that kind of practice; a practice where the people are robbed of their freedom to intuition.

\section{A KANTIAN ANALYSIS OF BERGSON'S CONCEPT OF OBLIGATORY MORALITY}

The driving force of Bergson's open morality is the relegation of the terms of obligation. His primordial position becomes that of freedom, and this freedom leads to creativity. In his view, obligation restricts and limits creativity and openness to humanity as a whole.

According to the analysis of Hobbes (1969:231):

In the state of nature, all humans are equal and equally have the right to whatever they consider necessary for the survival of equality. It means that people are capable of hurting their neighbors and taking what they feel they need for them own protection.

The prevailing point here is that, the open morality as described by Bergson champions the freedom of the person. To this end, any advocacy of a kind of morality that has no guide in terms of law and regulation would mean a return to the state of nature.

The open morality should also not be too quick to lose consciousness of the kind of freedom it clamors for in the human society. The world "right" as explained by Hobbes in the state of nature is a person's freedom but this freedom he further describe as freedom to do what he would and against whom he thought fit and to possess, use and enjoy all that he would and could get. The foregoing suggests that societal freedom from 
obligation could only be fruitless and no other relevance. It is in this regard that Mortimer Alder (1985: 176) unequivocally refers to this socio-political agenda as an error. His words:

The mention of complete autonomy as incompatible with living in society under government brings us to one other characteristically modern error about human society ... the error consists in thinking that it is possible for men to live together peacefully and harmoniously in the society without government and without laws made effectively, the exercise of coercive force.

Hegel (1967: 265), one of the greatest philosophers on the function of the state also made crucial contributions when he writes: "Institutions are the firm foundation, not only of the state but also of the citizen's trust and sentiments towards it."

Any attempt to eliminate these foundations will only pave way for the will to survive which is obviously the driving force in every person. In this scenario one pictures a society in which everybody is relentlessly pursuing whatever act they think will secure their safety, people moving against each other, bodies in motion or the anarchic condition which Hobbes (1969: 199) calls "war of all against all."

For a better understanding of the flow in the open morality of Bergson, we shall employ psychological consideration and consequences of his entire project. In analyzing human motivation, it is quite clear that everyone possess a twofold endeavor, namely appetite and aversion. These two endeavours account for a person's motions to and from persons and objects. These endeavours have the same meaning as the words love and hate. People are attracted to what they feel can make them survive and hate whatever they judge to be threat to them. In another sense, Enoch Stumpf in his description of Hobbesian state of nature asserts:

The words of good and evil have whatever meaning each individual will give them and people will call good whatever they love and evil whatever they hate... humans are fundamentally egoistic in that they are concerned chiefly about their own survival and identify goodness with their own appetites (Stumpf 1983: 231).

It would appear that in the kind of society that Bergson talks about, there would be no obligation for humanity to respect others. Given this egoistical view of human nature, it would appear also that humanity does not possess the capacity to create an ordered and peaceful society.

It appears from the foregoing that challenge of obligation that comes from the society and the presenting of the individual or God as the ultimate standard of judgment would only result in the collapse of societal structure. There can be no society when there is no law or obligation to balance exercise. According to Asouzu whenever a person or society lives from the maxim of consequence, self-interest, devoid of and disregard for the common good, will soon finds itself in artificial state of war and terror (Asouzu 2004: 22).

Open morality falls short of the Kantian moral standard. In his view, matters of morality should not in any way and under any consideration be dependent on inclination. Kant puts it more succinctly in these words: "A person is acting moral only when he suppresses his or her feeling and inclination and does that which he or she is obliged to do (Kant 2002: 36).” 
Thus the only way that one can be said to be acting morally is when one's duty is been carried out with any sense of inclination to that behavioural pattern. Thus doing one's duty is doing something that one is not inclined or willing to do but that he or she does because he or she recognized that he or she must fulfill it. Morality in this case is closely bound up with one's duties and societal obligation.

We shall also quickly recall that one of the most renewed critics of the terms of open and dynamic morality is the categorical imperative of Kant. The categorical imperative is an unconditional imperative. It does not command one to do something which is a means to another end; what it commands is good in itself. It commands action not as means to an end but as good in themselves. It admits no exception; no if or conditions is attached to it. Hence, unlike the open morality, it obliges all men without exception. This is astutely referred to as moral imperative that is, the imperative of the moral law. The imperative of morality is absolute and categorical and nobody can be exempted from it.It is thus moral characteristic that Kant calls "apodictic practical principles" (Kant 2002: 78).

Hegel criticizes this as an unacceptable dualism similar to that of Descartes. It is an over simplification to split man into two opposing parts. Pure reason and animal passions are always in conflict with each other. According to Kant, actions done in accordance with natural inclinations or in accordance with one's emotions, sentiments or feelings have no moral value. In order to have moral values, an action must be done in opposition to ones' natural inclination, emotions or sentiments, and it must be done purely for the sake of duty. Hence, the moral life involves constant struggle between man's rational will and natural inclination. Hegel criticizes this as involving a contradiction. Joseph Omoregbe (2012:229) asks if this struggle were successfully brought to an end in favour of the rational will, that is, if rational inclinations were completely suppressed so that the rational will would no longer meet any opposition, would man's actions then have any moral values?

In Kant's ethics such actions which involve no struggle on the part of the rational will have no moral value. Of course, such a rational will that does not encounter any opposition from natural inclinations would be a "holy will", the will of a perfectly rational being. This would mean moral perfection which Kant says is unattainable here on earth. The struggle between the rational will and natural inclination is an endless struggle.

Hegel argues that Kant's ethics is not really sincere since he does not want to see an end to the struggle he is engaged in because it is precisely thus struggle that gives his actions their moral values. It is in the end to this struggle which Kant denies that the open morality of Bergson fits in and this corresponds to the supra-intellectual thought.

The outright regulation of obligation by the open society has continued to attract universal attention. This is simply a resultant of the wide spread belief of the indispensability of social obligation. It has also been argued that obligation springs from the evolution of the human society over the years. It is therefore a 
development that cannot be hurriedly separated from the society and the individuals. Anthony Parel seems to have a similar view when he says:

Social obligation lies at the basis of closed society. To put it briefly, social obligation is a product and requirement of the evolutionary process that created the human species. The need arises because of the need to reconcile sociality and intelligence. In the animal kingdom, sociality is maintained in societies composed of intelligent beings through social obligation which is immanent in the individual (Stumpf 1983: 233).

In human societies it plays a role analogous in that played by the instinct in the animal community. Its most common manifestations are through the beings to conform their behavior to the requirement of society. The totality of obligation exerts an irresistible quasi-intellectual force on the individual. In his conclusion to the two sources of morality and religion, Bergson holds a force of unvarying direction, which is to the soul what force of gravity is to the body, ensures the cohesion of the group by bending all individual will to the same end and that force is moral obligation (Stumpf 1983: 266).

The social ego should therefore be seen as subsisting in the individual ego. It becomes almost impossible to engage in any project of separating the individual from the society which harbors his or her identity. That the analysis of the data of evolution draws our attention to one of the very serious credit to chased society is not an overstatement. In his preliminary statements to the open morality, Bergson says that "the evolution has made man for small societies and not for humanity as such (Bergson 1935: 56)" In furtherance of this point he says; there is destruction between social values and human values, from the one, we do not reach the other by way of natural progression but by way of intuitive leap. There is also distinction between fundamental nature as produced by evolution and acquired cultural nature as produced by civilization.

The last point that will be considered in this regard and even more importantly at that is the political system. Can a political regime for the values of open morality open up innocently to the entire humanity as though it does not project and preserve the interest of its state first? Of the three historical patterns of political regimes, monarchy and oligarchy are nearer to being closed and the third which is democracy is further removed and closest to being open. Democracy is not to be a product of natural social evolution but the outcome of mystical intuition of the absolute worth of human beings. It is evangelical in essences and love is its motivating force.

But even at this, democracy which seems to be closest to being open is not free from the conditions of closed society. This is for the simple reason that any society that has to defend itself from others similarly organized is obliged to rely on values of closed society. Wars are therefore a perfect test of whether a society is closed or open. 


\section{CONCLUSION}

Thus far, we have pre-occupied ourselves with the criticism of forceful morality, using Bergson's open society as a major tool. It has evolved from this paper that obligation harbors a myriad of deleterious consequences for humanity. It has been the major reason for our almost paralyzed systems. It lends a helping hand to deceptive approach to human relations: the love of man for the sake of force. The presence of obligation has shut the door to authentic relations with the society and humanity. In the absence of the law enforcer, the individual would act contrary to that law.

The renowned Bergsonian initiative comes with the central focus of widening human conception of morality, relegating the societal and community arbitrary pressure. He challenges every man and woman to open up to the universal requirement of morality. A moral understanding that makes human love fellow human as a direct resultant of conviction, a conviction devoid of every societal pressure, a conviction that is precipitated by desire and aspiration. Our understanding of the terms of this kind of system puts us above the dictates of obligation, personalities here are above the general and conventional run of things, personages in this moral understanding build their tent with the historical heroes of morality, men who have dedicated their lives to superlative moral standard living up to natural expectation even without any external force.

Before now we have stated that the disparate laws of obligation restrict and limit us to the confines of the society. In this case its focus is the preservation of the society, the survival and preservation of one's natural group becomes the ultimate pre-occupation obligation. The close outcome of societal preservation, virtual hostility towards other groups, is against all other human beings. The final content of obligation is precipitated by the purview which is hostility. Hostility gives birth to the desire for expansion of one's group domination and imperialism, violence and war. It is against this barbaric attitude of a particular society to another that the morality of aspiration and desire, which does not just seek the good of any particular society but the universe. The open morality advocates the peaceful co-existence of the whole human community through personal conviction and understanding of the essential meaning of the love of humanity and love of the universe.

As it is the earlier we learn to neglect the reign of obligation the better for the development of the community and the Nigerian nation in general. This move opens our society to attracts ingenuity and creativity. The call for the subjugation of obligatory morality becomes fiercer with the initiative and critique of Bergson. Hence, it would be sufficiently proper that any group that must make any noticeable progress should as a matter of necessity be considerably open, for it is a common place that obligation is an adequate representation of stagnation, it does not have much regard for either human and societal change, forgetting so fast that the only constant in the entire universe is change. With the Bergsonian evolution the best comes with the expiration of time, hence he defines becoming as enduring. 
Universally, there is a frantic search for an open morality, a morality which is all-encompassing and that appears to account for the whole world's desire for democracy as a better option of the system of government. Taking together, we shall sympathetically remark that, the open morality has not come to abolish the values of the closed or obligatory morality but to revamp and change the system into one that reverses and preserves human dignity and supra-rational initiative.

\section{UMA ABORDAGEM KANTIANA PARA O CONCEITO DE MORALIDADE OBRIGATÓRIA DE HENRI BERGSON}

\section{Resumo}

O artigo usa os princípios morais de Immanuel Kant para examinar o conceito de moralidade obrigatória por Henri Bergson. Henri Bergson sustenta que a sociedade é a causa e a fonte da obrigação que, obviamente, implica que o senso de obrigação é um senso de pressão social. Por conseguinte, a voz do dever não é algo misterioso proveniente de um mundo inimaginável, mas sim a voz da sociedade. Consequentemente, se alguém estiver em conformidade com as diretrizes dessas regras, isso significaria resistência a si mesmo. Portanto, quando alguém é moralmente obrigado a agir de forma específica, ele se refere à crença de que o ato é prescrito por um conjunto de valores. O imperativo categórico de Kant sustenta que, se um ato for limpo, ele deve ser universalizado para que qualquer outra pessoa em situação similar realize essa ação. Portanto, a questão é: como conciliamos os ditames da sociedade com o imperativo categórico de Kant? O documento é de natureza expositiva, crítico em perspectivas e método analítico. Ele usa o padrão ético de Kant como seu modus operandi no discurso da moralidade obrigatória de Henri Bergson.

Palavras-chave: moral obrigatória, moral aberta, moral fechada, sociedades nos indivíduos.

\section{REFERENCES}

ABIA, V. 2002. Understanding Nigerian Politics and Government. Lagos: Concept Publisher.

ADLER, J. 1952. Great Books of Western World. Chicago: Encyclopedia Britannica.

ASOUZU, I. 2004. The Methods and Principles of Complementary Reflection in and Beyond Africa Philosophy. Calabar: University of Calabar Press.

AUDI, R. 1991. Cambridge Dictionary of Philosophy. London: Cambridge University Press.

BERGSON, H. 1973. Matter and Memory. Tans by Paul, N. M. and Palme, W. S. London: Allen and Unwin, ltd, 1913.

1935. The Two Sources of Morality and Religion, Trans. R. A. Audra and Bereton, C., New York: Double Day and Company, Inc.

1946. The Creative Mind, Trans. By Anderson, M. New York: The Philosophical Library, Inc. 
COPLESTON, F. 1975. A History of Philosophy. Vol. 9, Great Britain: Burns and Oates.

EDWARDS, P. 1952. The Encyclopedia of Philosophy, Vol. 7, New York: Macmillian and Free Press.

HEGEL, F. 1967. Philosophy of Right, Trans. By Knox, T. London: Oxford University Press.

HOBBES, T. 1969. Leviathan, Pensium Books.

HENRICH, T. 2005. The Oxford Companion n Philosophy. New York: Oxford University Press.

KARL, P. 1962. The Open Society and its Enemies, Vol. 1. Preceton: New Jersey Press.

KAUFMAN, W. 1970. Hegel's Political Philosophy. New York: Atherton Press.

KENNEDY, P. 1993. Preparing for the Twenty-First Century. New York: Random House.

MACPHERSON, C. B. 1962. The Political Theory of Possessive Individualism: Hobbes to Locke. London: Oxford University Press.

MORTIIMER, J.1985. Ten Philosophical Mistakes. New York: Macmillan Press.

MONDIN, B. 1985. Philosophical Anthropology. Trans. By Myroslaw, C., Rome: Urbanian Press.

OLADIPO, O. 2006. Core Issues in African Philosophy. Ibadan: Hope Publication.

OMOREGBE, J. 2012. A Simplified History of Western Philosophy, Vol. 1. Lagos: Joja Press, Ltd. 2012. Knowing Philosophy. Lagos: Joja Educational Press Ltd.

OYESHILE, O. A. 1998. Compendium of Philosophical and Political Quotations. Ibadan: Hope Publications.

STUMPF, S. E. 1983. Philosophy: History and Problems. New York: McGraw-Hill Book Company.

TAYLOR, C. 1979. Hegel and Modern Society. Cambridge: Cambridge University Press.

TONNIES, F. C. 1957. Community and Society. Trans. By Charles, P. Michgan: The Michgan University Press.

TSENAY, S. B. 1991. African Philosophy: The Essential Reading. New York: Paragon House.

\section{INTERNET SOURCES}

http://Wikipedia.org/wiki/Henri Bergson.

http://Wikipedia.org/wiki/moral obligation.

http://Wordnet.princeton.edu/perl/webwn.

www.philosophypages.com.

Trabalho enviado em 24 de maio de 2017.

Aceito em 28 de junho 2017 